\title{
LIMA VAZ: POR QUÊ PENSAR O ABSOLUTO?
}

\author{
Lima Vaz: why thinking the Absolute?
}

Carlos Roberto Drawin *

Resumo: $\mathrm{O}$ presente artigo divide-se em três partes. Na primeira parte são apresentadas algumas notas sobre o itinerário intelectual de Lima Vaz a partir de suas entrevistas e depoimento autobiográficos de modo a ressaltar simultaneamente a sua abertura para as inquietações de sua época e o rigor e consistência de sua investigação. Na segunda parte são feitas algumas indicações acerca de sua apropriação da filosofia hegeliana a partir de sua opção metafísica. Na terceira parte procurou-se mostrar a sua concepção de pensar o Absoluto não decorre de uma decisão arbitrária e baseada em suas convicções religiosas, mas responde à necessidade de criticar as aporias suscitadas pelos humanismos antropocêntricos. No final do texto, à luz do pensamento de Lima Vaz, são feitas algumas poucas considerações sobre a filosofia heideggeriana.

Palavras-chave: Absoluto. História. Espírito. Dialética. Humanismo.

Abstract: This article is composed by three sections. The first one presents some aspects of the intellectual path of Lima Vaz, based on his interviews and autobiographic testimonies in order to highlight both his openness in addressing the concerns of his time and the rigorous consistency of his philosophical research. The second part focuses on his approach to Hegelian philosophy as a source of inspiration for his metaphysical stance. The third and final part tries to expose that Lima Vaz's conception of the Absolute does not come from an arbitrary decision based on his religious convictions. Rather, it answers the need of criticizing questions raised by the anthropocentric humanistic point of view. Finally, there are some considerations on Heideggerian philosophy in its relation to Lima Vaz's thinking.

Keywords: Absolute. History. Spirit. Dialectics. Humanism.

* Doutor em Filosofia. Professor aposentado do Departamento de Filosofia da UFMG e Professor Titular da Faculdade de Filosofia e Teologia (FAJE). Artigo recebido em 28/02/2021 e aprovado para publicação em 01/03/2021. 


\section{Um itinerário intelectual}

A obra de Lima Vaz fascina e desconcerta o leitor por algumas de suas raras e surpreendentes qualidades. Num primeiro contato ao 1 se obter a informação de ser o autor um padre católico e jesuíta logo se pode insinuar a suspeita, bastante comum atualmente, acerca de obras apologéticas e enquadradas na doutrina romana. Nada de intelectualmente estimulante pode provir daí, senão as mesmas e entediantes repetições dogmáticas. O descarte rápido, todavia, logo é contido se o interesse persistir o tempo suficiente para um rápido folhear de alguns de seus livros: a erudição, registrada na riqueza e diversidade da bibliografia, das citações e notas inibe o gesto mais fácil da desconsideração. Não se espera de obras doutrinárias, em seu afã de persuasão rápida, o aparato crítico e acadêmico com que logo se depara quem prosseguir na leitura. Mais surpreendido ainda ficará o suposto leitor ao se deparar com a dificuldade do percurso a ser empreendido, não pela obscuridade da linguagem ou cultivo do hermetismo, mas antes por essa infrequente associação de clareza e rigor na construção de um pensamento original e sistemático. A clareza com que se assume e desenrola o argumento proposto e o rigor das muitas e nem sempre óbvias mediações conceptuais convocadas em sua demonstração.

Assim foi desde o início o itinerário do jovem filósofo católico. Desde sua graduação, feita ainda nos moldes estritos da escolástica, não se ateve aos limites dos manuais então dominantes, porque a superfície aparentemente calma de sua organização formal o incitou a mergulhar nas águas mais profundas de suas origens clássicas: o estudo acurado de Platão, de Aristóteles e São Tomás de Aquino. O prosseguimento de seus estudos na Europa, numa Roma vivendo ainda no rescaldo e reconstrução do pós-guerra, confirmaram a sua vocação metódica levando-o a se debruçar na filosofia platônica, já concebida, numa intuição jamais desmentida ao longo de seu percurso, como a matriz primordial de inteligibilidade do pensamento ocidental. Cabem aqui algumas observações sobre a sua formação: a disciplina adquirida nos exercícios escolásticos não foi deixada para trás, mero obstáculo a ser superado, porque lhe propiciou o primeiro impulso de sistematização; o ideal do intellectus fidei o afastou tanto do fideísmo, aurido apenas da efusão emocional, quanto do intelectualismo intuicionista ou reducionista, ambos impacientes com o penoso trilhamento das mediações conceptuais. Em sua tese doutoral, versando sobre contemplação e dialética nos diálogos platônicos, retoma a interpretação de Festugière sobre a vida contemplativa, debruçando-se aos textos com minúcia e atenção, sem perder o olhar amplo de sua investigação acerca do aspecto epistemológico da perquirição platônica. Nela quis mostrar o caráter científico e discursivo da dialética cuja "unidade terminal", a Ideia de Bem, "é conhecida não por 'êxtase' ou 'contato inefável', mas precisamente em 
sua razão de 'princípio' e 'fim' do mundo ideal..." ${ }^{1} \mathrm{Na}$ conclusão de sua tese já se encontra "uma primeira e indecisa influência hegeliana...ao interpretar a nóesis em Platão como um resultado intrinsecamente ligado ao caminho - ou ao método dialético, e não como uma intuição inefável e quase mística". ${ }^{2}$

Não obstante, a força de sua formação e de sua aguda consciência do significado do trabalho intelectual, não sufocou o seu interesse pelas questões candentes e ideias mais desafiantes de seu tempo. Na graduação já havia o interesse pela ciência moderna, a recepção das primeiras ressonâncias do existencialismo e o fascínio pelo neotomismo de língua francesa, chegado a Roma, deixa-se entusiasmar pela florescente théologie nouvelle. ${ }^{3} \mathrm{O}$ olhar para o passado, a investigação das fontes jamais desmentida ou abandonada, não impediu a atenção às contradições do presente. Retornando da Europa para lecionar na austera faculdade jesuíta de filosofia, situada nas montanhas de Nova Friburgo, distante da agitação da capital carioca, a sobriedade do filósofo se encontra com os fortes ecos políticos e sociais daquele momento. Encontro nada surpreendente se considerarmos que o mergulho nas fontes propiciava, justamente pelo ímpeto de seu jorro, o ir para frente, no seguimento do grande caudal da história da filosofia. Tal navegação, no entanto, não se faz num rio abstrato, sem leito e sem margens, porque os acidentes geográficos interferem em seu curso e o navegador não pode permanecer indiferente às mutações e diversidade das paisagens. Além disso, o exercício da filosofia não se restringia à rotina docente, porque provinha do chamamento presente em toda inteligência verdadeiramente filosófica, aquela exemplarmente definida por Hegel e assumida por Lima Vaz, de "conceituar o que é" e fazê-lo transcrevendo o próprio tempo no pensamento. ${ }^{4}$ Para ele, assim como para o filósofo alemão, a filosofia surgia de uma coerção $a b$ intra e não do arbítrio do filósofo, emergindo como necessidade histórica e lógica "como forma de razão no seu trabalho de suprassumir as oposições (Gegensätze) que caracterizam a cisão (Entzweiung) da cultura...(ela) se impõe quando o "poder de unificação" (Macht der Vereinigung) desaparece da vida dos homens e a cultura passa a ser dominada pelo Entendimento (Verstand) que é a faculdade do finito". ${ }^{5}$

\footnotetext{
${ }^{1}$ LIMA VAZ, Henrique C. de. Contemplação e dialética nos diálogos platônicos. Tradução do latim para o português feita por Juvenal Savian Filho. São Paulo: edições Loyola/Fapemig, 2012. p. 238. Trata-se da reedição da tese doutoral depositada em 1952 e defendida na Universidade Gregoriana em 1953. Nas referências bibliográficas as obras de LimaVaz estão ordenadas cronologicamente.

${ }^{2}$ Cf. LIMA VAZ, Henrique C. "Meu depoimento" (1976). In: LADUSANS, Stanislavs. Rumos da filosofia atual no Brasil em autorretratos. São Paulo: Edições Loyola, 1976. p. 303-304.

${ }^{3}$ Cf. Idem (1976). p. 300-301

${ }^{4}$ Cf. HEGEL, Georg W.F. Linhas fundamentais da filosofia do direito ou Direito Natural e ciência do Estado em compêndio. Tradução Paulo Meneses [et al.]. São Leopoldo: Editora UNISINOS, 2010. p. 43

${ }^{5}$ Cf. LIMA VAZ, Henrique C. de. (1997c). Escritos de filosofia III. Filosofia e cultura. São Paulo: Edições Loyola, 1997. p. 51. Ver: HEGEL, Georg W.F. “Différence entre les systèmes philosophiques de Fichte et de Schelling". In: HEGEL, Georg W.F. Premières publications. Traduction, introduction et notes de Marcel Méry. Paris: Éditions Ophrys, 1964. p. 77-190.
} 
Desde seu primeiro magistério, transcorrido ainda no mundo contido e silencioso da Faculdade de Filosofia de Nova Friburgo, se deu a apropriação criteriosa do pensamento moderno e não o deixou alheio aos problemas, desafios e turbulências de sua época. A discrição e timidez do padre jesuíta em nada impediam o vigor de suas reflexões filosóficas cujos ecos chegaram aos ouvidos dos jovens universitários católicos premidos por seu engajamento social e político a buscar subsídios intelectuais que preservassem a sua identidade cristã, igualmente distante quer do conservadorismo de extensos segmentos eclesiais, quer da forte atração exercida pelo marxismo. Aqueles anos sessenta do século passado eram febris e conturbados, agitados por intensa criatividade artística e cultural e por grandes expectativas de transformação da sociedade brasileira em sua busca de combater a desigualdade, o atraso em seu desenvolvimento socioeconômico e se afirmar em sua soberania. Nesta conjuntura os escritos do Padre Vaz, como a partir de então ficou largamente conhecido, se disseminaram e foram absorvidos rapidamente embora sem jamais se deixarem contaminar pela ligeireza das formulações e urgências da militância. Por isso mesmo neles já avultavam aquelas qualidades raras acima aludidas. Os seus textos colhiam as inquietações e contradições da história vivida discriminando alternativas e assumindo posições nítidas, procurando se distanciar tanto do materialismo histórico e do nacionalismo eclético, quanto do reacionarismo avesso a qualquer mudança estrutural. Os filósofos acadêmicos, representados, sobretudo, pelo Departamento de Filosofia da Universidade de São Paulo, desprezavam essas tendências mais engajadas e cultivavam a tecnicalidade recém conquistada de sua profissão, não economizando no recurso aos mais sofisticados instrumentos filológicos e conceituais e se indispondo a fazer concessões às sínteses fáceis. Daí, conforme depoimento insuspeito, a admiração e respeito com que os textos de Lima Vaz eram recebidos por todos, ainda que a filosofia acadêmica se mantivesse respeitosamente distante, seguindo a via da especialização historiográfica e exegética com os efeitos paradoxais da elevação do nível da pesquisa e de certo insulamento com relação ao debate público. ${ }^{6}$

A ruptura traumática do golpe civil-militar de 1964 encerrou aquela interação de fecundidades e equívocos entre a militância católica de esquerda e o filósofo sensível, porém incapaz de sacrificar a integridade de sua investigação em nome das injunções do momento. A sua vida pessoal já estava firmemente encaminhada, mas poderia fazer sua uma adaptação da divisa cartesiana: "quod mentis sectabor iter?". O percurso a ser buscado e lentamente construído não poderia se perder em perplexidades vãs, uma vez aurido pelo "inesquecível humanismo friburguense" e norteado pela tradição clássica e tomista. ${ }^{7}$

${ }^{6}$ Cf. ARANTES, Paulo E. “Um depoimento sobre o Padre Vaz". Síntese. Revista de Filosofia. Belo Horizonte, v. 32, n. 102 (2005): 5-24.

${ }^{7}$ Cf. Idem (1976). p. 304-305. 
Assim, tendo ido lecionar no Departamento de Filosofia da UFMG, recolheu-se às montanhas mineiras de sua origem ouro-pretana, não para cevar desencantos e ressentimentos, senão para adentar com ainda maior tenacidade no continente da racionalidade moderna cuja exploração já chegara no final dos anos cinquenta nas escarpas do grande maciço hegeliano. Afastado das pressões mais imediatas da práxis, os anos de magistério na UFMG - sobretudo nos quinze anos transcorridos entre a preparação da comemoração do segundo centenário do nascimento de Hegel, em 1970, e a sua aposentadoria em 1986 - revelaram-se extraordinariamente proveitosos, pois neles se deu o labor paciente e desafiante da apropriação do sistema hegeliano, entregando-se a "uma leitura mais minuciosa e mais exegética dessas obras que, para nós, eram muito difíceis". ${ }^{8}$

Por conseguinte, pode-se acompanhar no itinerário intelectual de Lima Vaz, desde os seus primórdios friburguenses, a recepção especulativa das contradições de sua época, com suas limitações e riquezas. As vicissitudes do tempo instigam o seu filosofar e nele encontram a sua expressão crítica e reflexiva. Para usar a imagem platônica, que lhe era tão cara, a ascensão especulativa para o Uno, brotando da experiência da dispersão e da multiplicidade, não se mantém no espaço rarefeito da pura contemplação devendo retornar à fugacidade do vivido e lhe dar algum sentido ou, antes, um sentido radical. Assim, como já se disse, a controvérsia política que lavrava no meio da militância universitária cristã o levou ao estudo de Marx e a leitura dos "Manuscritos" marxianos de 1844 lhe impôs a entrada no vasto e inesgotável território hegeliano. A passagem de Marx a Hegel, inverte a direção cronológica e subverte a ideia simplista do progresso filosófico, porque permite desvelar, na compreensão a posteriori, as aporias ontológicas subjacentes ao materialismo histórico. Vê-se a razão de seu primeiro livro, publicado em 1968, intitular-se "Ontologia e história", afirmando desde o início como a atenção aos embates do tempo podem sem perder na insensatez sem o norte do pensamento do ser.

Ao realizar o aparente recuo de Marx a Hegel a interpretação de Lima Vaz produz um efeito hermenêutico de grande relevância, permitindo-lhe explicitar o caráter inconciliável entre o pressuposto materialista, a limitação proveniente em última instância da natureza material em sua determinação finita e a lógica dialética proveniente do espírito em seu dinamismo in-finito. Portanto, se, como escreve Marx nos "Manuscritos", "a "supressão da propriedade privada" como efetivação do comunismo, seria "o enigma da história finalmente resolvido", então não se vê como se daria tal resolução. $\mathrm{Na}$ perspectiva materialista da primazia ontológica da natureza seria possível prefigurar o "fim" ou realização da história como "humanização total da

${ }^{8}$ Cf. LIMA VAZ, Henrique C. de. (1997a). "Filosofia e forma da ação. Uma entrevista de Henrique Cláudio de Lima Vaz". Cadernos de filosofia alemã. N. 2 (1997): 77-102. p. 79. 
natureza (e) espontaneidade absoluta da consciência" ou, ao contrário, confluiria na "naturalização total do homem"? ${ }^{9}$ Neste texto, publicado originalmente em 1959, Lima Vaz procura mostrar, no caráter inconciliável do materialismo e da dialética, onde se assenta "a aporia mais profunda do humanismo marxista, na qual um imenso e generoso esforço de promoção do homem encontra-se frente a frente com o risco de sua desumanização total". ${ }^{10}$

A já mencionada coletânea de textos de 1968 cobre o período de dez anos (1954-1963) no qual o jovem doutor de formação clássica e ainda começando a sua docência acolhe em sua reflexão as demandas de uma sociedade convulsionada por conflitos sociais e políticos. As duas partes em que se divide a obra - "temas de ontologia" e "a reflexão sobre a história" não são superpostas e nem traduzem uma solução de compromisso provisória, porque neles apenas se entreouve o fragor das alternativas em choque na necessária distância da serenidade especulativa. Assim, nos seus artigos mais difundidos e mais influentes em sua época assume "a original historicidade da consciência ou sua abertura para o ser-no-tempo", explicitando a inevitável participação do cristianismo nas lutas políticas e embates ideológicos que então ocorriam, sem por isso flertar em momento algum com o relativismo historicista. Os confrontos políticos e ideológicos não podem ser negados, nem inteiramente resolvidos apenas no choque empírico dos antagonismos e prescindindo da dimensão ontológica. Ao interditar o acesso à instância da fundamentação e da justificação filosóficas, o relativismo historicista vai erodindo a viabilidade das mediações discursivas para ceder o seu lugar à violência pura. ${ }^{11}$ Não há nessa advertência a ingenuidade de se acreditar vivendo num mundo sem violência no qual tudo se resolve pelo diálogo. Ao contrário, é justamente por reconhecer a violência em sua inegável presença e a lastimável frequência de suas manifestações que não se deve a ela conceder o privilégio da ultima ratio e mais se faz necessária a insistência nas instâncias discursivas e normativas. Há ainda outra razão para resistir tanto às facilidades do historicismo, quanto à ideologia do progresso inexorável que o complementa. A violência não se apresenta apenas em suas formas mais visivelmente cruentas também se encontra embutida no progresso, sob a roupagem do humanismo moderno. A aposta prometeica na criação de um mundo inteiramente conforme aos cânones da racionalidade técnica não interromperia o dinamismo transcendental da subjetividade levando o homem a voltar-se contra si mesmo? Por isso, adverte Lima Vaz,

“tal 'projeto' de 'humanização' científico-técnica da natureza - o mais revo-

lucionário e o mais audaz - traz inscrito, em sua essência, uma profunda

\footnotetext{
${ }^{9}$ Cf. Marx, Karl, apud LIMA VAZ, Henrique C. (1959) "Marxismo e ontologia". In: LIMA VAZ, Henrique C. de. Ontologia e história. São Paulo: Edições Loyola, 2001a. p. 121-161. Ver. p. 124 e p. $121-128$.

${ }^{10}$ Cf. LIMA VAZ. Idem. p. 125.

${ }^{11}$ Cf. LIMA VAZ, Henrique C. (1960) "Cristianismo e consciência histórica I". In: LIMA VAZ, Henrique C. de. Ontologia e história. São Paulo: Edições Loyola, 2001a. p. 165-187.
} 
ambiguidade e formula-se como um risco supremo para o homem. Não comporta ele a ameaça de uma anulação da subjetividade, devorada por seus próprios instrumentos (sua ciência e sua técnica), de sorte a ser perder o mistério da pessoa na anônima e implacável 'função planificadora' de uma pseudo-humanidade de pesquisadores e técnicos?"12

O temor formulado interrogativamente neste texto publicado há sessenta anos se mostra hoje em sua dura realidade, embora na época em que o artigo foi publicado, no contexto do otimismo desenvolvimentista e das expectativas utópicas do segundo pós-guerra, já tendo sido esquecidas as sucessivas catástrofes do século, tais inquietações poderiam ser atribuídas à mentalidade religiosa e ainda conservadora do autor, embalado pela nostalgia de uma visão de mundo definitivamente ultrapassada. O leitor poderia passar por cima desses temores e advertências para reter tão somente a sua perspectiva modernizadora, a do avanço histórico da emancipação. Contudo, tal leitura não faz justiça à coerência do argumento apresentado.

\section{A exigência especulativa}

Conforme sua modesta declaração, durante mais de uma década o filósofo fez a detalhada e árdua travessia da obra hegeliana, sem pretender tornar-se um especialista no filósofo alemão, "um hegelianista no sentido estrito da palavra". Mesmo porque a seriedade científica do trabalho não tinha motivação acadêmica, sendo o seu intuito compreender as alternativas e impasses de um mundo no qual o "programa marxista" suscitava acalorados debates. Como já foi dito, o encontro com os "Manuscritos econômico-filosóficos" de Marx o fez ver a impossibilidade de apreender o significado da inversão materialista sem o estudo aprofundado da "Fenomenologia do espírito". ${ }^{13}$

A inversão marxiana foi, por sua vez, invertida no reconhecimento da impossibilidade de se percorrer a exposição fenomenológica das figuras da consciência sem o balizamento dos momentos dialéticos fundados na "Lógica" e integrados no conjunto do sistema. Afastando-se, assim, das leituras antropológicas e existenciais da "Fenomenologia" baseadas na valorização unilateral de seu célebre capítulo quarto acerca da dialética do "Senhor e do Escravo" e na desconsideração do pensamento do Absoluto posto como seu resultado e como seu ponto de partida.

Divergindo da interpretação de Alexandre Kojève, cujo poder de sedução consistia em privilegiar a luta pelo reconhecimento, facilmente apreensí-

${ }^{12}$ Cf. LIMA VAZ, Henrique C. de (1961). “Cristianismo e consciência histórica II". In: LIMA VAZ, Henrique C. de. Ontologia e história. São Paulo: Edições Loyola, 2001a. p. 189-217. p. 215.

${ }^{13}$ Cf. LIMA VAZ, Henrique C. de. (1997a). Op. Cit. P. 78 
vel pela ótica marxista, porém bloqueando o desdobramento dialético da razão em sua natureza sistemática e substancial e calando o seu sentido metafísico e, dessa forma, desembocando nas diversas formas do humanismo antropocêntrico. Aliás, fenomenologia de Hegel, assim o disse explicitamente Kojève numa carta de 1948 a Tran-Duc-Thao, foi por ele colocada a serviço de uma antropologia filosófica cujo núcleo consistia na concepção do ser humano como espírito e deste como negação temporal da natureza em sua materialidade exterior. A negação, todavia, circunscrita à ação histórica do homem, se desvinculava de seu vínculo dialético com a natureza e a ideia. Desse modo, o ser humano, mesmo concebido como espírito, se origina da natureza em sua exterioridade material e para ela retorna. Kojève ilustrou a sua concepção através da imagem de um anel: a natureza é o ouro e o homem o vazio, o buraco central do anel, daí decorrendo a prevalência ontológica da natureza. De onde provém a força de negação do espírito humano se em si mesma a natureza é cega? Carente de sentido metafísico o espirito se dilui no éter da negação abstrata e o seu fim não pode ser outro senão a satisfação das necessidades oriundas daquela mesma natureza inicialmente negada. $\mathrm{O}$ "fim da história" coincidiria com a satisfação das necessidades biológicas e a entrada no gozo "humano, demasiado humano", dos prazeres e lazeres que seriam a todos acessíveis. ${ }^{14}$

Lima Vaz, recusando o pressuposto antropocêntrico, assumiu o movimento intrínseco do sistema hegeliano no qual a "Fenomenologia" possui

“uma face histórica, porque as experiências [nela] recolhidas são experiências de cultura, de uma cultura que se desenvolveu no tempo sob a injunção do pensar-se a si mesma e de justificar-se ante o tribunal da Razão. Uma face dialética, porque a sucessão das figuras da experiência não obedece à ordem cronológica dos eventos, mas à necessidade imposta ao discurso de mostrar na sequência das experiências o desdobramento de uma lógica que deve ao momento fundador da Ciência: ao saber absoluto como adequação da certeza do sujeito com a verdade do objeto" ${ }^{\prime 15}$

Não se pode separar e menos ainda estabelecer uma oposição externa entre a Fenomenologia e o Sistema porque a primeira é

"uma leitura ...pela perspectiva da consciência que se forma. Perspectiva tipicamente moderna, no sentido da filosofia do sujeito...ao passo que o

\footnotetext{
${ }^{14}$ Ver, JARCZYC, Gwendoline e LABARRIÈRE, Pierre-Jean. De Kojève à Hegel. Cent cinquante ans de pensée hégélienne en France. Paris: Albin Michel, 1996. p. 64-69. A discussão sobre o significa do "fim da história" é bastante extensa entre os intérpretes de Hegel: teria sido o império napoleônico, a vitória do comunismo real, como acreditou certa vez Kojève ou o fim da Guerra Fria e a pacificação neoliberal do mundo? Não entro aqui neste debate, apenas reitero a posição de Lima Vaz.

${ }^{15}$ LIMA VAZ, Henrique C. de (1981). "Senhor e escravo: uma parábola da filosofia ocidental". Síntese. Nova Fase. Vol. VIII, n. 21 (1981): 7-30. p. 10.
} 
sistema é o que começa depois da Fenomenologia: uma vez que a consciência atinge o Saber absoluto. ${ }^{16}$

Por outro lado, a processão das figuras da consciência se assenta em sua estruturação lógica, na identidade dialética entre sujeito e substância, certeza e verdade, estando o fim, como já se disse, presente no começo. Caso contrário, o isolamento da perspectiva da consciência arruína a inteligibilidade da história e converte o humanismo moderno, apesar de toda sua altiloquência retórica, em mera ilusão antropológica. Estranho caminho trilhado pela crítica da ilusão teológica quando a racionalidade aparentemente triunfante acaba por se transfundir no mito. A emancipação almejada, que seria decorrente da superação da particularidade cultural das religiões, se desvanece no "mau infinito" (schlechte Unendlichkeit), isso é, na pura, infindável e impotente negação de todos os limites do finito. ${ }^{17}$

Preso nas malhas de suas necessidades naturais e de busca de satisfação, a realização da liberdade converte-se em mito, torna-se uma projeção imaginária num futuro mitificado como forma de dominar o fluxo caótico das circunstâncias aleatórias. Poder-se-ia, neste caso, concordar com a ironia nietzscheana: diante da grandeza e impassibilidade do universo o animal humano em sua ridícula pequenez não passa de um breve momento de arrogância, um gemido prestes a desaparecer na eternidade cósmica silenciosa e indiferente. ${ }^{18}$

O alcance antropológico da Fenomenologia só pode ser medido, conforme Lima Vaz, à luz dos três silogismos do sistema apresentados nos parágrafos finais da Enciclopédia. No primeiro (par. 575), o sistema é apresentado em seu desenvolvimento linear como Lógica-Natureza-Espírito segundo a sequência discursiva da Enciclopédia e que tem o seu centro na exterioridade da natureza. No segundo (par. 576), apresentado como Natureza-Espírito-Lógica é o silogismo da reflexão, porque tem o seu centro no espírito ou no ato filosófico como ato espiritual que realiza a mediação entre a natureza e a lógica. Nestes dois primeiros silogismos o Logos, a Natureza e o Espírito são "divisões" ou "manifestações" da Ideia. No

\footnotetext{
${ }^{16}$ Cf. LIMA VAZ (1997 a). Op. Cit. p. 82.

${ }^{17}$ Cf. LIMA VAZ, Henrique C. de. (1970) Ateísmo e mito. A propósito do ateísmo do jovem Marx. Revista Portuguesa de Filosofia, 26 (1970): 20-50. p. 29.

${ }^{18}$ Cf. NIETZSCHE, Friedrich. Sobre verdade e mentira no sentido extra-moral. São Paulo: Hedra, 2007. p. 25. Aqui abre-se uma discussão de vital importância em suas consequências éticas e políticas. De maneira frequente Hegel é visto como um adepto da mais estrita necessidade lógica transposta pelo marxismo de influência positivista como implicando a aceitação de leis férreas para a história. Outros irão ressaltar na dialética a dimensão da contingência, como se vê na interpretação de Hegel proposta por Lebrun e orientada por uma estratégia nietzscheana. Ver: LEBRUN, Gérard. O avesso da dialética. Hegel à luz de Nietzsche. São Paulo: Companhia das Letras, 1988. Uma discussão estimulante e algo idiossincrática a respeito se encontra em: ZIZEK, Slavoj. Menos que nada. Hegel e a sombra do materialismo dialético. São Paulo: Boitempo, 2013. P. 32-107.
} 
terceiro silogismo (par. 577), apresentado como Espírito-Lógica-Natureza, tem o seu centro o próprio Logos, o inteligível em e para si mesmo. ${ }^{19}$

Nessa formulação o inteligível não se esgota na natureza ou no espírito finito, embora neles se manifeste e, por conseguinte, o Lógico (das Logische) reúne no movimento diferencial da identidade sob três aspectos: o abstrato do Entendimento (Verstand), o negativo-racional da mediação dialética e o positivo-racional da Razão especulativa. ${ }^{20}$

Isso significa que a história humana deve ser concebida não como um epifenômeno da natureza em sua materialidade e nem como uma deriva arbitrária da consciência, porque pode ser apreendida em sua inteligibilidade, como realização da liberdade. No entanto, em razão de seu caráter absoluto, o inteligível não é uma propriedade da história em sua imanência, temporalidade e finitude. Não há algo como um progresso inexorável ou assegurado da liberdade, pois esta é sempre uma fulguração ou um acontecimento contingencial do Absoluto. Por isso, o espírito na história surge como "negatividade absoluta", bem diferente da negatividade antropológica propugnada pela interpretação antropocêntrica, como aquela propugnada por Kojève, tão difundida e exaltada pelo humanismo emancipatório. A rememoração filosófica da história no plano da exposição fenomenológica se fez segundo o domínio do silogismo da reflexão: o desenvolvimento do Espírito Subjetivo partiu da consciência em sua aparição mais imediata, a certeza sensível, para chegar ao Saber Absoluto. No entanto, a sua inteligibilidade não é uma conquista progressiva da humanidade rumo à plena emancipação porque, como observa bem André Léonard, vista na forma do terceiro silogismo, a centralidade do Logos é irredutível à imanência do devir temporal. Ao contrário, a história se mostra, em seu "poder revelador", "como desapropriação indigente e reapropriação negativa do espírito: o calvário do Absoluto". ${ }^{21}$

Como já havia sido estabelecido por Platão, não se pode renunciar ao "ponto de vista" especulativo se a multiplicidade e a contingência forem pensáveis. A correlação de Platão e Hegel, como duas culminâncias especulativas, já havia sido intuída na conclusão de sua tese doutoral:

Num sentido em que já se podia perceber uma primeira e ainda indecisa influência hegeliana - mas a referência a Hegel aparece apenas nas últimas linhas da minha tese - busquei interpelar a nóesis em Platão como um re-

\footnotetext{
${ }^{19}$ Cf. LIMA VAZ, Henrique C. de. (1997c). Escritos de filosofia III. Filosofia e cultura. São Paulo: Edições Loyola, 1997. p. 74-75.

${ }^{20}$ HEGEL, Georg W.F. Enciclopédia das ciências filosóficas em compêndio (1830). Vol. I. São Paulo: Edições Loyola, 2017. p. 159-169. Ver, CARON, Maxence. Être et identité. Méditation sur la Logique de Hegel et sur son essence. Paris: Les Éditions du Cerf, 2006. p. 149-159.

${ }^{21}$ Cf. LÉONARD, André. "L' Absolut et l'histoire". In: VV.AA. Hegel et la théologie contemporaine. Paris/Neuchatel: Delachaux et Niestlé Éditeurs, 1977. p. 81-93. p. 88. Ver, HEGEL, Georg W. F. (1807) Fenomenologia do espírito. Tradução: Paulo Meneses. Petrópolis: Vozes; Bragança Paulista, Editora Universitária São Francisco, 2014. p. 33.
} 
sultado intrinsecamente ligado ao caminho - ou ao método - dialético, e não como uma intuição inefável e quase mística. Se se pensa que o caminho dialético, na condição terrestre da alma, se desenvolve no tempo, vê-se que o problema se coloca no terreno das relações entre o "a priori" da Ideia, dada na reminiscência, e os métodos dialéticos de descoberta da própria Ideia, os quais têm lugar na situação temporal da alma, isto é, na História. ${ }^{22}$

Neste testemunho pessoal, bem posterior àquela primeira intuição feita ainda nos primeiros passos de sua investigação, Lima Vaz já pode reconstruir o seu próprio itinerário intelectual como um grande arco metafísico que parte da "posição arquetipal do platonismo nas estruturas mentais do Ocidente e da teologia crista $\tilde{a}^{\prime \prime}$ para chegar à filosofia hegeliana do espírito como uma espécie de cume a descortinar o agitado e confuso panorama do pensamento contemporâneo. Hegel, já se observou, não o interessa como objeto específico de pesquisa acadêmica, mas por ocupar uma posição privilegiada na compreensão da dialética da modernidade. ${ }^{23}$

Por que tomar Platão e Hegel como referências filosóficas matriciais? Não haveria aí uma escolha motivada pelo arbítrio doutrinário? Não há dificuldade em constatar que a opção de vida e as vicissitudes da formação têm papel relevante na constituição de qualquer obra intelectual. A filosofia nasce fora da filosofia, busca sua seiva no topos da vida concreta, nos entrechoques de um chão cultural particular. Todavia, para retomar a definição hegeliana, a sua transcrição conceptual possui um alcance atópico ao traduzir a variedade e exuberância dos acontecimentos e experiências, a desordem do mundo vivido, numa ordem de razões. ${ }^{24}$

Poder-se-ia objetar: por quê deveria haver alguma "ordem de razões"? Tal pretensão de ordenação não constitui uma violência à realidade? A objeção não pode ser aqui abordada com merecido vagar e ponderação. $O$ faço de um modo um tanto abrupto: o homem sendo um ser de linguagem não pode permanecer fechado numa vivência afásica e todo discurso, por mais disruptivo que pretenda ser, Nietzsche bem o viu, não pode escapar da força ordenadora intrínseca à linguagem. Por isso, o anúncio reiterado da morte da filosofia ou de sua realização na práxis impõe sempre o recurso de uma nova justificação reflexiva como um renascer "das mesmas perguntas primeiras que a Razão tem diante de si...sob (uma) nova forma de conjuntura ideo-histórica". ${ }^{25}$ Talvez se possa dizer que a necessária configuração discursiva possa se limitar a segmentos bem delimitados e objetivos da experiência fenomênica, como é o caso das ciências positivas ou a relatos bem circunscrito a avessos ao impulso originário do Logos como "fundamento, ordem e finali-

${ }^{22}$ Cf. LIMA VAZ (1976). Op. Cit. p. 303-304.

${ }^{23}$ Cf. LIMA VAZ (1976). Idem. p. 303 e 305.

${ }^{24}$ Cf. LIMA VAZ (1997c). Op. Cit. p. 3-16.

${ }^{25}$ Cf. LIMA VAZ, Henrique C. de. (1991b). "Morte e vida da filosofia". Síntese. Nova Fase. Vol. XVIII, n. 55 (1991): 677-691. p. 681. 
dade ${ }^{26}$ Sem dúvida, o impulso originário do Logos pode ser intrrompido, em nome da prudência epistemológica ou do respeito à diversidade das culturas. Todavia, deve-se reconhecer, que os problemas contemporâneos rompem as barreiras disciplinares da especialização científica e os seus desafios irrompem no interior de todas as configurações culturais particulares. A sua extensão planetária e a intensidade de suas consequências na trama narrativa da vida parecem requerer justamente aquela radicalidade interrogativa da razão que, às vezes, se pretendeu sufocar. A "destruição da razão", em seu sentido ontológico e ético, a sua deslegitimação relativista coincidiu com a expansão da racionalidade técnica, legitimada por sua potência pragmática, ou seja, por sua hegemonia efetiva. Não se trata de uma questão secundária, afeita ao gosto acadêmico, porque não há qualquer garantia prévia contra a autodestruição de nossa civilização, risco agravado pela corrosão relativista de nossa "faculdade de reagir de modo adaptado aos desafios do tempo" em decorrência da "aniquilação do sistema imunológico intelectual e psíquico". ${ }^{27}$ Por outro lado, a tópica de nossa época, isto é, o solo problemático da experiência contemporânea alimenta em suas contradições intrínsecas, o movimento interrogativo do Logos, obrigando as interdições naturalistas e culturalistas tão em voga a se confrontarem com a sua autorrefutação. ${ }^{28} \mathrm{~A}$ obra de Lima Vaz não deve ser lida a partir da determinação extrínseca de sua opção de vida e de sua formação, mas como resultado da percepção aguda da crise do tempo presente e de seu incansável empenho em apreendê-la em seu significado filosófico por meio de um argumento complexo e de denso travamento conceptual. Somente nesta perspectiva a sua "opção metafísica" deixa de ser entendida como uma decisão arbitrária, decorrente de uma inteligência nostálgica e conservadora para ser avaliada em sua indesmentível atualidade.

\section{Por quê pensar o Absoluto?}

O texto ó Absoluto e a história", que encerra a coletânea de 1968, teve como objetivo discutir o estatuto ontológico da categoria de "consciência histórica" iniciando a reconstrução crítica que iria desaguar mais de vinte anos depois na antropologia e na ética sistemáticas. ${ }^{29}$ Ora, a noção de

\footnotetext{
${ }^{27}$ Cf. HÖSLE, Vittorio. La crise du temps présent et la responsabilité de la philosophie. Nîmes: Théétète Éditions, 2004. p. 32-33.

${ }^{28}$ Cf. THOMAS-FOGIEL, Isabelle. Référence et autoréférence. Étude sur le thème de la mort de la philosophie dans la pensée contemporaine. Paris: Vrin, 2005. p. 7-66.

${ }^{29}$ O livro "Ontologia e história", publicado em 1968 e reeditado em 2001, reúne diversos artigos do período de 1959 a 1963, quando Lima Vaz estava em contato com os jovens universitários cristãos politizados e desenvolvia as suas reflexões no contexto dessa proximidade com as demandas da ação política. O último texto do livro "O absoluto e a história" foi publicado na revista "Paz e Terra" um pouco depois, em 1966 e, portanto, após o golpe civil-militar de 1964 quando a situação política tinha se modificado substancialmente.
} 
consciência histórica emergiu como resposta à necessidade de pensar a inserção dialética do homem no mundo enquanto "ser histórico" visando ultrapassar "as fronteiras de um pensamento lógico limitado à ordenação da realidade em quadros fixos e estáticos". ${ }^{30}$ No entanto, à luz da análise fenomenológica a consciência não é vista como um receptáculo vazio e nem como um dado opaco, porque compreendida em seu dinamismo na conjunção de dois polos, o da intencionalidade voltada para o polo da objetividade e o da expressividade, retornada ao polo da subjetividade. Essa polarização intica que apesar de sua atividade "sintética e unificadora", "não sendo o homem sujeito absoluto, solus ipse" a consciência é "uma conquista gradual sobre a multiplicidade e dispersão dos objetos" ${ }^{31}$ Nessa abordagem processual o "ato de consciência" se revela em sua historicidade, tanto na vertente da universalidade da intenção, quanto na vertente do aprofundamento da expressão, ambas se realizando como comunicação das consciências no plano simbólico da cultura. Sendo este mediado pelo trabalho de transformação da natureza, pelo necessário atravessamento da realidade objetiva sem, porém, a ela se reduzir. ${ }^{32}$ Se assim for, uma vez vedada a explicação unilateral da cultura por meio da causalidade material, a sua condição de possibilidade consiste no compartilhamento de um mundo de significações, pois "não seria possível a comunicação entre os homens se ao menos as grandes linhas de uma mesma visão do mundo não se cruzassem num espaço comum de inteligibilidade". ${ }^{33}$

Esse "espaço comum de inteligibilidade" não é estático, possui um sentido histórico,

"por outro lado, o risco e a presença das alienações mostram que a consciência histórica, como razão na história, nunca se constitui totalmente como razão da história. Tal caso-limite representaria a sua própria supressão dialética: nele, com efeito, a realidade do mundo e do outro teria sido assumida na total transparência do ato de consciência. A história teria tocado o seu fim" ${ }^{34}$

Se a história for a pura dispersividade dos acontecimentos não se pode falar de razão na história e prevalece o relativismo como um "fenomenismo absoluto", pois todo "conteúdo de verdade" se dissolve nas "condições de seu aparecer". Nem mesmo se poderia falar em aparecer, porque não haveria um "algo" que aparece e nem um sentido histórico porque toda ideia de sentido estaria arruinada. $O$ falar, tangenciando a afasia, se implodiria na incomunicabilidade, o humano regressaria à dimensão de sua pura natu-

\footnotetext{
${ }^{30}$ Cf. LIMA VAZ, Henrique C. de (1966). "O absoluto e a história” (1966). In: LIMA VAZ, Henrique C. de. Ontologia e história. São Paulo: Edições Loyola, 2001 a. p. 247-278. Ver, p. 247-248.

${ }^{31}$ Cf. LIMA VAZ (1966). Idem. p. 250. Ver p. 250-254.

${ }^{32}$ Cf. LIMA VAZ (1966). Idem. p. 258.

${ }^{33}$ Cf. LIMA VAZ (1966). Idem. p. 262.

${ }^{34}$ Cf. LIMA VAZ (1966). Idem. p. 263.
} 
ralidade e no lugar de "total transparência", teríamos a "total opacidade". A noção de consciência histórica emergiu na perspectiva da história ser concebida "como um processo de humanização, como advento progressivo do reino do homem", embora ela seja insuficiente se não for elucidada em suas diversas dimensões. ${ }^{35}$

A modernidade poderia ser considerada, então, como a época da vitória incontestável do humanismo? A resposta seria certamente negativa se considerarmos a diferença irredutível entre a "razão na história" e a "razão da história" impedindo a convergência dos acontecimentos e das diversas configurações culturais numa plenitude imanente. Por que diferença irredutível? Porque a expressividade da consciência é sempre particular, marcada pela finitude de sua condição temporal, enquanto a intencionalidade da consciência é constitutivamente universal, projetando-se na in-finitude da demanda de sentido. Em seu aspecto instrumental a consciência histórica responde às situações particulares e nelas se expressa e ao fazê-lo, ao narrar as condições específicas de sua própria gênese abre um novo espaço de possibilidade e significação. O dinamismo transcendental ínsito na capacidade narrativa da consciência histórica, não podendo ser explicado por sua gênese no tempo exige, para sua justificação filosófica, a passagem para os planos normativo e ontológico. Caso contrário a intencionalidade universal da consciência seria barrada e sucumbiria à voragem da contingência, no devir do não sentido. Não há como evitar essa conclusão senão aceitando a projeção mítica de um fim imanente da história no qual a subjetividade em geral e os sujeitos singulares que a encarnam se desvaneceriam no total objetivismo. Aceitar a solução imanentista radical levaria à uma estranha situação hermenêutica: a realização da humanidade consistiria na erradicação do humano no homem uma vez que sua marca distintiva radica no dinamismo transcendental presente na subjetividade e na linguagem. Seria a redundância de uma hermenêutica da eliminação de toda hermenêutica, seja por dissolvê-la na dispersão irremediável das contingências, seja por emudecê-la na incomunicabilidade do objetivismo. A exigência ontológica do Absoluto não é introduzida de modo arbitrário, senão como exigência absoluta da lógica que é posta pela consciência histórica. Por isso Lima Vaz conclui a sua exposição como se segue:

O Absoluto de exigência está presente na contextura essencial da história: sua posição é exigida pela oposição que permanece na relação intersubjetiva entre a infinitude intencional entre os sujeitos que se encontram e a contingência e limitação de sua situação-no-mundo, de sua condição empírica. Ele não se identifica, entretanto, com o processo histórico. Para que seja dialeticamente "superada" a oposição do sujeito e do mundo e a pluralidade espácio-temporal dos sujeitos - o risco, em suma, de sua perda na condição de objeto - é necessário que a intenção da consciência vise ao Absoluto a

${ }^{35}$ Cf. LIMA VAZ (1966). Idem. p. 265 ss. 
um tempo como imanente à consciência-de-si e à relação intersubjetiva (isto é, como fundamento radical do seu ser) e como transcendente à limitação real dos sujeitos e à própria contingência do processo histórico. ${ }^{36}$

Está traçado aqui, numa publicação de 1966, apesar de diversos deslocamentos e rearranjos conceptuais, o referencial fundamental do qual nunca se afastará: a manifestação do Absoluto na história e sua diferença irredutível a qualquer ordem imanente, seja a natureza ou a cultura. Em alguns aspectos a categoria de "consciência histórica" respondia às demandas da práxis num momento conflitivo e esperançoso da sociedade brasileira e, apesar das advertências antes mencionadas, era tributária de uma modernidade ainda não suficientemente avaliada em seu niilismo. A patologia niilista não era fenômeno de superfície e atingia o coração mesmo do humanismo moderno atingindo inclusive as suas expectativas utópicas. Num texto bem posterior a presença de um certo otimismo com relação ao progresso é posta em questão ao afirmar que tendo prevalecido "durante o século XI e boa parte do século XX" o "dogma do progresso" foi sendo "profundamente atingido (pela) perda constante de credibilidade" e, na esteira dos tormentos do século XX suas "últimas décadas...viveram, na verdade, uma crise generalizada envolvendo todos os grandes projetos culturais da modernidade: o social, o ético, o político, o pedagógico" ${ }^{\prime \prime 37} \mathrm{O}$ desfile patético dos humanismos modernos em suas muitas feições - ateu, científico, pragmatista, positivista, evolucionista e existencialista - desembocou no "espírito anti-humanista" do final do milênio. ${ }^{38}$ Apesar de suas diferentes faces a processão dramática dos humanismos traz a marca de sua origem comum estruturalmente antropocêntrica. A atmosfera de desencanto e demissão, acabou envolvendo todos os projetos de construção da vida em comum e deixou em seu rastro o imaginário compensatório e sempre frustrante da satisfação individual.

A anterior euforia do humanismo antropocêntrico com sua aparência solar não mais esconde a escuridão do niilismo conforme foi profeticamente definido por Nietzsche num fragmento do outono de 1887: "falta a meta; falta resposta ao "por quê? ...o fato de que os valores supremos se desvalorizaram". ${ }^{39}$ Seria talvez, assim parece crer o filósofo alemão, o raiar de um novo dia? $\mathrm{O}$ apogeu de um outro meio-dia cuja luminosidade não fosse mais proveniente do já envelhecido e declinante sol platônico? Qual seria a via de acesso à essa nova "potencialidade do espírito" finito? Outro fragmento de Nietzsche talvez nos ofereça um vislumbre da hercúlea tarefa:

Não temos mais absolutamente nenhum senhor sobre nós; o antigo mundo valorativo é teológico - ele passa por uma reviravolta - Dito de uma

\footnotetext{
${ }^{36}$ Cf. LIMA VAZ (1966). Idem. p. 278. p. 266-278.

${ }^{37}$ Cf. LIMA VAZ, Henrique C. de. (2001) "Humanismo hoje: tradição e missão". Síntese. Revista de Filosofia. Vol. XXVIII, n. 91 (2001): 157-158.

${ }^{38}$ Cf. LIMA VAZ (2001). Idem. p. 159

${ }^{39}$ Cf. NIETZSCHE, Friedrich. Fragmentos póstumos (1885-1887). Vol. VI. Tradução Marco Antônio Casanova. Rio de janeiro: Forense Universitária, 2013. p. 289.
} 
maneira: não há nenhuma instância mais elevada sobre nós: até o ponto em que se pode haver Deus, nós mesmos somos agora Deus...precisamos conferir a nós os atributos que atribuíamos a Deus. ${ }^{40}$

A citação acima é imediatamente seguida pelo fragmento intitulado "a lógica do ateísmo" no qual retoma a "fórmula clássica" do personagem Kírilov do romance "Os demônios" de Dostoiévki e segundo a qual se a existência de Deus é necessária e se ele não existe, então "não se pode mais viver". ${ }^{41}$ Deixando de lado o intrincado dos aforismos nietzscheanos, pode-se dizer que Lima Vaz assume filosoficamente a impossibilidade da tarefa de transferir ao homem os atributos de Deus e as consequências de seu fracasso, conforme se vê no "desconserto sobretudo de natureza ética que se propaga de maneira quase irresistível por todos os campos de nossa cultura". ${ }^{42}$ Ao invés de um grande "sim!" à vida, domina a inércia e perplexidade diante de uma realidade indiferente à intencionalidade dos atores sociais, o florescer da "vontade de potência" dá lugar ao sentimento de impotência e parece cada vez mais difícil conceber alternativas ao curso do mundo em seu efetivo funcionamento. Por isso adverte Lima Vaz:

O reino da anomia generalizada no qual vem terminar o ambicioso projeto do humanismo antropocêntrico (o que) oferece, pois, um desmentido flagrante a um de seus dogmas mais arraigados. Pensar o ser humano a partir de Deus não significa aliená-lo na esfera de um imaginário inconsistente. Ao contrário, o que a história recente nos mostra é que nunca a imaginação humana assistiu a uma tal proliferação de ídolos, a uma tal gestação de pseudo-absolutos quanto nesses tempos de proclamado reinado do homem. ${ }^{43}$

O que fazer diante do desmoronamento niilista do humanismo moderno? A expansão planetária da racionalidade técnica e sua penetração intensiva no mundo da vida não se apresenta como uma resposta para a crise espiritual na qual encontra-se mergulhada a civilização ocidental, agora tornada mundial, ao menos numa perspectiva sistêmica. Por quê designá-la como espiritual? Porque a ideia de espírito reúne em seus múltiplos significados diferentes dimensões ontológicas da experiência humana: a penetração da realidade pela inteligência e sua tradução discursiva (noûs, logos), a sua estrutura transcendental como autorreflexividade e consciência de si (synesis) e, não menos importante, por sua abertura e dinamismo, carnalidade e historicidade (pneûma). Enquanto razão, seu aspecto inteligível, o espírito, é necessariamente unitário, enquanto vida, seu aspecto histórico, o espírito é necessariamente inacabamento. ${ }^{44}$ Por isso na antropologia sistemática de

\footnotetext{
${ }^{40}$ Cf. NIETZSCHE, Friedrich. Fragmentos póstumos (1887-1889). Tradução Marco Antônio Casanova. Vol. VII. Rio de janeiro: Forense Universitária, 2012. p. 130.

${ }^{41}$ Cf. NIETZSCHE, Friedrich. Idem. p. 131.

${ }^{42}$ Cf. LIMA VAZ, Henrique C. de. (1997b) "Atualidade da sabedoria antiga". Síntese Nova Fase. Vol. XXIV, n. 78 (1997): 411-420. p. 412.

${ }^{43}$ LIMA VAZ, Henrique C. de. (2001) "Humanismo hoje: tradição e missão". Síntese. Revista de Filosofia. Vol. XXVIII, n. 91 (2001): 157-168. p. 165.

${ }^{44}$ Cf. LIMA VAZ, Henrique C. de. (1991a). Antropologia Filosófica I. São Paulo: Edições Loyola, 2001. p. 203; p. 212.
} 
Lima Vaz, a categoria de espírito, como coroamento das estruturas fundamentais do ser humano, abre a passagem para as estruturas relacionais da objetividade, da intersubjetividade e da transcendência e não pode ser inteiramente circunscrita pelo discurso antropológico:

“O espírito não pode ser considerado, em sua amplitude transcendental como uma estrutura ontológica do homem em sua vinculação irrevocável com a contingência e finitude, como o são o somático e o psíquico. O espírito é, segundo a terminologia clássica, uma perfectio simplex: em si mesmo atualidade infinita de ser. Por isso mesmo, é pelo espírito que o homem participa do Infinito ou tem indelevelmente gravada em seu ser a marca do Infinito. Se a noção de espírito transcende os limites da conceptualidade antropológica, é claro que sua atribuição ao homem só é possível segundo uma analogia de atribuição na qual o princeps analogatum é o Espírito Infinito ou Absoluto e o espírito, no homem, é um analogatum inferius" ${ }^{45}$

Por quê, sendo espiritual, a crise não pode ser devidamente enfrentada por algum tipo de racionalidade objetiva e funcional? Porque as propriedades da objetividade e da funcionalidade, pertencentes a uma categoria antropológica específica e não sendo transferíveis para a totalidade do humano, impõem a pluralização da razão em racionalidades específicas voltadas para um recorte particular da realidade e da experiência. Esse "processo (moderno) de auto-diferenciação da razão" manifesta e responde à transformação tanto do método, quanto do sujeito do conhecimento. O método deixa de ser direcionado para o ser ou essência das coisas e volta-se para a reconstrução analítica dos fenômenos. Por outro lado, com a redução do transcendental à estrutura formal condicionante do conhecimento o sujeito deixa de ser concebido segundo a sua vinculação ontológica com o mundo, produzindo, assim, o colapso ético que irá corresponder no plano ideológico à ascensão do individualismo. ${ }^{46}$ Há nesse processo um duplo esvaziamento, o da restrição epistemológica da essência inteligível da realidade, levando à abundância dos meios de realização material do ser humano, e o da restrição antropológica da intencionalidade transcendental da subjetividade, levando à escassez dos "fins capazes de dar sentido à aventura humana". ${ }^{4}$

A hipertrofia da racionalidade técnica, assim como de qualquer outra racionalidade funcional, aprofunda o desequilíbrio entre meios e fins e não pode, portanto, por princípio, ser adequada para o enfrentamento da crise espiritual consistindo, antes, em ser o seu efeito e sintoma. Por isso testemunhamos um destino surpreendente de nossa lógica civilizacional, a dominação técnica da natureza e o crescimento econômico da sociedade

${ }^{45}$ Cf. LIMA VAZ (1991a). p. 202.

${ }^{46}$ Cf. LIMA VAZ, Henrique C. de. (1995). "Ética e razão moderna". Síntese Nova Fase. Vol. XXII, n. 68 (1995): 53-85. p. 60-61.

${ }^{47}$ Cf. LIMA VAZ (1995). Idem. p. 55. 
seguem um desenrolar aparentemente inintencional. As inegáveis conquistas técnicas e econômicas, com seus muitos e benvindos benefícios, produzem consequências catastróficos e o progresso racional se inverte na irracionalidade de sua autorreprodução incoercível e as mercadorias em excesso são devoradas em sua significância existencial pelas circunstâncias, diluídas na irrelevância e o ser humano cindido entre o acaso e a necessidade perde-se no "som e da fúria" dos acontecimentos.

O duro diagnóstico não se deve à adesão a um hipotético catastrofismo como projeção pessimista do futuro. A reprodução automática das condições vigentes no presente torna desde já a "terra inabitável", não somente pela destruição efetiva e quase irreversível do meio ambiente, mas também porque toda habitação pressupõe a familiaridade com uma finalidade compartilhada ou, como diz Heidegger, consiste, "no modo da finitude" em "ser trazido à paz de um abrigo... permanecer pacificado na liberdade de um pertencimento, resguardar cada coisa em sua essência". ${ }^{48}$

Não havendo uma finalidade dotada de sentido , a humanidade, conforme a expressão utilizada por Günther Anders, entra no "tempo do fim", o que não significa estarmos na eminência do término da espécie, de já termos chegado ao "fim dos tempos", mas em ter de lidar com a possibilidade efetiva de sua autodestruição, porque com o advento da era nuclear e o prosseguimento irrefreado da intervenção maciça na natureza, adentramos num tempo no qual pela primeira vez na história foi adquirido um poder multiplamente suficiente de aniquilação, tanto da vida do humano em sua nudez biológica, quanto do humano da vida em sua riqueza simbólica. Compreendendo o empobrecimento simbólico como a crescente contração do "tempo do mundo" num presente bloqueado do passado e da tradição, cada vez mais distanciado do patrimônio da tradição, divorciado do "espaço da experiência" e incapaz de imaginar o futuro e a emancipação, cada vez mais descrente do "horizonte de expectativa". ${ }^{49}$

Talvez tenhamos ingressado naquela hora crepuscular propícia para investigar as raízes profundas do destino de nossa civilização para então discernir os acontecimentos originários de seu extravio. Nesta perspectiva avulta a concepção heideggeriana da metafísica como devir de uma opção inaugural, aquela feita por Platão e convertida em configuração

\footnotetext{
${ }^{48}$ Cf. HEIDEGGER, Martin. "Construir, habitar, pensar". In: HEIDEGGER, Martin. Ensaios e conferências. Petrópolis: Vozes, 2001. p. 125-141. p. 129. Para uma exposição dramática da destruição do meio ambiente, ver: WALLACE-WELLS, David. A terra inabitável. Uma história do futuro. São Paulo: Companhia das Letras, 2019.

${ }^{49}$ Cf. ANDERS, apud VIOULAC, Jean. La logique totalitaire. Essai sur la crise de l'Occident. Paris: PUF, 2013. p. 451-459. Ver também: KOSELLECK, Reinhart. Futuro passado. Contribuição à semântica dos tempos históricos. Rio de janeiro: Contraponto: Ed. PUC-Rio, 2006. p. 305-327 e ARANTES, Paulo. O novo tempo do mundo e outros ensaios sobre a era da emergência. São Paulo: Boitempo, 2014. p. 27-97.
} 
determinante de sua "constituição onto-teológica" e em sua deriva até o triunfo planetário da técnica. Não há lugar aqui para expor ou discutir a posição de Heidegger a partir de uma seleção mínima dos textos mais pertinentes de sua obra extensa e difícil. Seja como for, a sua evocação se justifica apenas porque a interpretação heideggeriana da metafísica se apresenta como a que mergulha mais profundamente nas raízes da crise da modernidade diagnosticada por Lima Vaz. Não obstante este a rejeita decididamente, apesar de reconhecer a sua genial originalidade. Para ele a chave hermenêutica unívoca utilizada por Heidegger seria inaceitável ao fazer do platonismo o "episódio inicial" e definidor de toda filosofia cujo episódio conclusivo seria o niilismo e a dominação técnica planetária. ${ }^{50}$ Para Lima Vaz a visão heideggeriana do conjunto da metafísica, mesmo reconhecendo a diversidade de suas manifestações, esta possuiria a mesma estrutura básica caracterizada como

\begin{abstract}
"uma dialética circular entre o Ser (Ens primum cognitum = on) como fundamento gnosiológico do conhecimento dos seres (entia) e, inversamente, a hierarquia dos seres tendo como cimo mais alto o Ente supremo (Ens summum), Princípio e Causa primeira (theos) como fundamento ontológico dos seres (implicando) a ocultação do Ser no impensado da diferença entre o Ser e os entes, e o seu esquecimento, fruto da abstração que conduz ao conceito universalíssimo do ens primum cognitum. Fica, assim, decifrado o destino do Ser tanto na filosofia primeira aristotélico-tomásica como na Ciência da Lógica hegeliana. De acordo, pois, com a leitura heideggeriana do destino da metafísica, há uma estrutura conceptual unívoca que subjaz à sua história: o Ser (on) e o divino ou Deus (theion, theos) estão em mútua dependência lógica e ontológica no lógos da metafísica". ${ }^{51}$
\end{abstract}

Segundo ele a abrangência excessiva da hermenêutica heideggeriana não levaria em consideração a singularidade e complexa interdependência de diversas configurações na história da metafísica ocidental como " $O$ neoplatonismo, a metafísica do ato de existir de São Tomás de Aquino e a revolução filosófica do século XIV".52 $\mathrm{O}$ exame da transição para o pensamento moderno seria de crucial importância não só para colocar em questão a interpretação unívoca da história da metafísica proposta por Heidegger, mas também porque pode mostrar o quanto essa interpretação ainda está surpreendentemente dependente da concepção contra qual pretende reagir e se apresentar como uma alternativa radical. Numa referência rápida e não muito cuidadosa da posição de Lima Vaz pode-se dizer que a primazia moderna da subjetividade decorre da "ruptura entre a representação e o ser" no ato do conhecimento, no contexto da profunda transformação filosófica ocorrida no século XIV levando à "inversão que passa a dar primazia à representação no regime do conhecimento, a ela submetendo a face

${ }^{50}$ Cf. LIMA VAZ (1997 c). Op. Cit. p. 344.

${ }^{51}$ Cf. LIMA VAZ (1997 c). Idem. p. 345-346.

${ }^{52}$ Cf. LIMA VAZ (1997c). Idem. p. 347-348. 
objetiva - o ser - do objeto conhecido". ${ }^{53}$ Desse modo vai sendo abandonada a solução proposta por Aristóteles e acolhida por São Tomás de Aquino para a solução do "problema da representação", isto é, para o problema gnosiológico decorrente da evidente diferença entre a presença física do objeto e sua presença mental. A solução aristotélico-tomista se sustenta na "identidade intencional" entre a inteligência cognoscente (noûs) e o ser inteligível do objeto (noetón) ocorrida no espaço mental da representação como meio no qual se dá o encontro entre a inteligência e o ser. Por conseguinte, o conhecimento não se detém na representação que é apenas o meio no qual se realiza a verdadeira finalidade do conhecimento que é a apreensão do ser do objeto, de sua forma real. Essa solução pressupõe a inteligibilidade intrínseca do ser apreensível não por intuição direta, mas na articulação analógica do discurso a partir da homologia entre ser e pensar. No entanto, se o conhecimento permanecer enclausurado no universo da representação, sem atravessá-lo, então a única forma de garantir a sua objetividade e alcance universal residiria no reconhecimento da estrutura transcendental do sujeito cognoscente. A metafísica da subjetividade surge do ofuscamento da ontologia clássica - do abandono da possibilidade de apreensão analógica do ser - e sua substituição pela problemática epistemológica da estruturação transcendental do universo da representação. ${ }^{54}$

Nessa perspectiva, a compreensão de Heidegger teria sido certeira ao promover o retorno à ontologia contra a prevalência filosófica da epistemologia, questionando genialmente o impensado kantiano das "estruturas do sujeito cognoscente", considerado como um " $X$ do qual nada sabemos e nem podemos em geral saber". Obliterar a interrogação acerca do ser do sujeito colocaria a sua fundamentação da ciência dependente da aceitação de um modelo particular de cientificidade, a geometria euclidiana e a física-matemática newtoniana. Em consequência, carente de explicitação ontológica adequada a filosofia transcendental se enfraqueceria abrindo as portas aos cientificismos e historicismos. Aos primeiros por sacrificar a densidade da experiência humana no altar erigido pelos cânones naturalistas. Aos segundos por atrelar a razão a formas específicas e, portanto, históricas de cientificidade, introduzindo a gênese e o relativismo no coração mesmo da subjetividade transcendental..$^{55}$

Heidegger teria visto com extraordinária acuidade os riscos entranhados no neokantismo e na valorização unilateral da epistemologia acarretando a

\footnotetext{
${ }^{53}$ Cf. LIMA VAZ (1997c). Idem. p. 159-160.

${ }^{54}$ Cf. LIMA VAZ (1997c). p. 156-166.

${ }^{55}$ Ver PRADELLE, Dominique. Généalogie de la raison. Essai sur la historicité du sujet transcendental de Kant a Heidegger. Paris: PUF, 2013. p. 45. Ver p. 10-70. A discussão proposta por Pradelle é bem mais minuciosa e complexa e feita a partir da fenomenologia de Husserl. Aqui tomei apenas a indicação do problema abordado pelo autor e o inseri na exposição da concepção de Lima Vaz e sua crítica à primazia da representação e à necessidade de "desantropologizar a razão e de uma "doutrina não subjetivista da subjetividade pura". Cf. PRADELLE. Idem. p. 27.
} 
produção de racionalidades díspares, abstratas e submetidas à primazia do objeto. Pode-se discernir aí certa convergência com a concepção de Lima Vaz acerca da ruptura entre ser e representação como ponto de origem do transcendentalismo enfraquecido do tipo kantiano. Não obstante, ele rejeita vigorosamente a via adotada pela hermenêutica heideggeriada por ter colocado a incontornável pergunta pelo ser do sujeito contra o pano de fundo impensado da metafísica do sujeito, introjetando-a em sua ontologia fundamental. Ao discernir esta dificuldade em sua ontologia fundamental Heidegger teria se encaminhado na direção da "viravolta" (Kehre) e da história do ser. ${ }^{56}$

A sua visão teria sido afetada pelo ambicioso projeto de "destruição da metafísica" impedindo-o de perceber a profundidade e as inter-relações complexas da revolução nominalista do século XIV, solo no qual a metafísica da subjetividade lançava as suas raízes. Não se trata apenas de um problema de historiografia filosófica, porque nela estaria em jogo a incompreensão da "estrutura de base" da metafísica que, apesar de suas diferenças de conteúdo, seria semelhante nos modelos platônico e hegeliano. Em ambos, como foi anteriormente assinalado, a força lógica presente na linguagem romperia a clausura antropológica da própria linguagem, sem com isso instaurar o império da razão autossuficiente. Ao contrário, a linguagem estaria permanentemente atravessada pela tensão entre fechamento e abertura, e a inteligência finita estaria sempre sendo acompanhada pelas sombras da opacidade e se perdendo nas veredas da equivocação. Se em Platão o "movimento essencial do logos filosófico...se cumpre seguindo o esquema vertical da ascensão e da descida", enquanto em Hegel "procede segundo a linha horizontal de um desenvolvimento dialético" ordenando a multiplicidade em suas manifestações históricas. ${ }^{57} \mathrm{~A}$ precedência do Uno jamais faz cessar a atração gravitacional da inteligência finita para a multiplicidade sensível da experiência e para a errância histórica dos acontecimentos. Não haveria, contudo, uma exclusão irremediável entre a verdade e a história, por isso não se poderia falar nem de um progresso da filosofia, semelhante ao da tecnociência, como também não se poderia falar do caráter subjetivo do conhecimento como uma interdição intransponível para o próprio conhecimento. A história do espírito na riqueza de suas expressões artísticas e religiosas, políticas e filosóficas não evidencia uma conquista progressiva da verdade e muito menos a sua instalação definitiva. Nem indica um "destino", o curso inexorável do encobrimento da verdade no "esquecimento do ser", antes atesta a transcendência da verdade em suas manifestações

\footnotetext{
${ }^{56}$ A compreensão do caminho tomado por Heidegger em direção à Kehre passa por sua contraposição à interpretação neokantiana de Crítica da razão pura a partir da Analítica Transcendental, sem fazer uma simples inversão da Analítica pela Estética, mas "remetendo a sensibilidade e o entendimento à fonte mais originária da imaginação produtiva". Cf. PRADELLE. Idem. p. 21.

${ }^{57}$ Cf. LIMA VAZ (1997 c). Idem. p. 55.
} 
diferenciais e imprevisíveis, embora comensuráveis e passíveis de serem reconstruídas pelo pensamento, como mostra a "recordação interiorizada" (Erinnerung) hegeliana. ${ }^{58}$ Esse caráter simultaneamente histórico e transcendental, no sentido clássico e consagrado pela terminologia escolástica, aponta para a fecundidade da via analógica na concepção do "ato de existir" (esse) como "primeiro inteligível" (próton noetón) que sendo irredutível a toda tentativa de sua transcrição na imanência da subjetividade, também é "fonte primeira da inteligibilidade, da qual participa o próprio sujeito afirmante enquanto sujeito finito". 59

Procurei esboçar brevemente algumas pistas da rejeição de Lima Vaz à alternativa de pensamento proposta por Heidegger, porém nem a minha competência e nem o propósito do texto permitiriam ira além disso. Seria possível discernir alguns canais de interlocução entre a tradição analógica e a visão heideggeriana da metafísica como onto-teo-logia? De qualquer modo a doutrina da analogia entis não se impõe por si mesma, porque se multiplicou em diversas versões a serem ainda reconstruídas numa perspectiva histórica e filosófica. Por outro lado, a "meditação" heideggeriana da metafísica não se restringe às fórmulas canônicas da "diferença ontológica" e da redução ôntica do ser e menos ainda à compreensão comum da "destruição da metafísica". Após a publicação de "Ser e tempo" e, sob o impacto da recepção vitalista e existencial da ontologia fundamental, Heidegger procede à redescoberta, num intenso debate com Kant, do significado metafísico da estrutura transcendental do sujeito. A separação kantiana de Sensibilidade e Entendimento tornaria o conhecimento impossível se as duas faculdades não se enraizassem na natureza humana, mas esta não pode ser vista como algo natural, mas como "um fundo abissal" (abgründiger Grund) de onde brota a compreensão do ser e, apesar de surgir do "sujeito", a ele pertence somente porque o transcende. ${ }^{60}$ Certamente em seu existir fático o Dasein está envolto na natureza, porém "na medida em que é transcendente ou livre ele é estranho à

\footnotetext{
${ }^{58}$ Cf. HÖSLE, Vittorio. Verità e storia. Studi sulla struttura dela storia dela filosofia sulla base di um'analisi paradigmática dell'evoluzione da Parmenide a Platone. Milano: Guerini e Associati, 1998. p. 108-114.

${ }^{59}$ LIMA VAZ, Henrique C. de (2002). Escritos de filosofia VII. Raízes da modernidade. São Paulo: Edições Loyola, 2002. p. 109. Ver p. 95-115. A aproximação feita por Lima Vaz entre Platão e Hegel e a sua retomada da via analógica, assim como a abertura de uma possível interlocução com Heidegger exigiria a retomada do desdobramento das categorias lógicas na "Grande Lógica" de Hegel uma vez que esta não pretende apresentar uma nova ontologia ou uma nova metafísica, mas antes dissolvê-las para assumir a posição especulativa da anterioridade lógica com relação à cisão do ser e do pensar. Até onde a via analógica poderia ser articulada à essa tarefa desconstrutiva da lógica hegeliana? A questão aqui posta fica sem ser respondida. Ver o texto coletivo do seminário sobre a "Grande Lógica" realizado na E.N.S. de Saint Cloud e com o apoio de Pierre-Jean Labarrière: BIARD, J. [et al.]. Introduction à la lecture de la Science de la Logique de Hegel. I. L'être.Paris: Éditions Aubier-Montaigne, 1981. p. 9-31. ${ }^{60}$ Cf. HEIDEGGER, Martin. Metaphysische Anfangsgründe der Logik im Ausgang Leibniz. Gesamtausgabe, vol. 26. Frankfurt am Main: Vittorio Klostermann, 1978.p. 110.
} 
natureza" (als transzendierendes, d.h, als freies ist das Dasein der Natur etwas Fremdes). A transcendência não se refere apenas ao significado epistemológico da relação sujeito e objeto e nem designa aqui, em seu significado teológico, o "excedente" e o "inacessível" ao conhecimento finito, mas em primeiro lugar, "a transcendência é a constituição originária da subjetividade de um sujeito" (Vielmehr ist die Transzendez die ursprünglische Verfassung der Subjektivität eines Subjektes). Trata-se da "transcendência originária do Dasein" (Urtranszendez des Daseins), pois a "subjetividade do sujeito...ser sujeito quer dizer transcender...existir é originalmente esse passo para-além (Überschreiten)" ${ }^{61}$ Não sendo uma exterioridade em relação ao sujeito e nem pertencente apenas à intencionalidade presente no ato cognitivo visando apreender o objeto, a transcendência é a condição ontológica de possibilidade de todo conhecimento e de toda ação. Não poderia ser, então, retomando as palavras de Lima Vaz, "fonte primeira de inteligibilidade"?

Insistir nos pontos de convergência entre pensadores distantes seria mero exercício acadêmico ou, bem pior, vão empenho de costurar uma filosofia eclética? Ou seria buscar nos traços comuns a comensurabilidade das diferentes manifestações do espírito? A abdicação de tal empenho não seria ceder ao relativismo e identificar a filosofia com um conjunto de narrativas díspares e conceder a última palavra à racionalidade técnica?

Como foi brevemente evocado, Lima Vaz compreendeu desde o início as gravíssimas consequências niilistas da "morte de Deus" e as enfrentou por meio do esforço ingente de pensar Deus na história. Teria sido mero arbítrio da crença religiosa? Por que, no entanto, teríamos de aceitar como evidentes o revestimento da religião com "a casca vazia da convicção subjetiva e do sentimento" e o enlaçamento do conjunto da racionalidade ao pressuposto formal da objetividade? ${ }^{62}$

Hegel percebeu, ainda em seus albores, a chegada da tragédia ética da modernidade como cisão entre a consciência moral do indivíduo e as imposições funcionais de uma totalidade abstrata. Como pensar tal cisão senão escapando do espaço claustrofóbico da imanência? Quod mentis sectabor iter? Lima Vaz respondeu às graves inquietações de seu tempo traçando de modo exemplar, em sua vida e em sua obra, o necessário e inadiável itinerário para o Absoluto.

\footnotetext{
${ }^{61}$ HEIDEGGER, Martin. Idem. p. 211-212. Devo essas referências e reflexões a J.-F. Courtine. Ver: COURTINE, Jean-François. Inventio Analogiae. Métaphysique et ontothéologie. Paris: Librairie J. Vrin, 2005. Esp. p. 86-92.

${ }^{62}$ Cf. WILLIAMS, Robert R. Hegel on the proofs and the Personhood of God. Studies in Hegel's Logic and Philosophy of Religion. Oxford: Oxford University Press, 2017. P. 1-5.
} 


\section{Referências bibliográficas}

ARANTES, Paulo E. "Um depoimento sobre o Padre Vaz". Síntese. Revista de Filosofia. Belo Horizonte, v. 32, n. 102 (2005): 5-24.

ARANTES, Paulo. O novo tempo do mundo e outros ensaios sobre a era da emergência. São Paulo: Boitempo, 2014.

BIARD, J. [et al.]. Introduction a la lecture de la Science de la Logique de Hegel. I. Lêtre. Paris: Éditions Aubier-Montaigne. 1981.

CARON, Maxence. Être et identité. Méditation sur la Logique de Hegel et sur son essence. Paris: Les Éditions du Cerf, 2006.

COURTINE, Jean-François. Inventio Analogiae. Métaphysique et ontothéologie. Paris: Librairie J. Vrin, 2005.

HEGEL, Georg W.F. “Différence entre les systèmes philosophiques de Fichte et de Schelling". In: HEGEL, Georg W.F. Premières publications. Traduction, introduction et notes de Marcel Méry. Paris: Éditions Ophrys, 1964. p. 77-190.

HEGEL, Georg W. F. (1807) Fenomenologia do espírito. Tradução: Paulo Meneses. Petrópolis: Vozes; Bragança Paulista, Editora Universitária São Francisco, 2014.

HEGEL, Georg W.F. Enciclopédia das ciências filosóficas em compêndio (1830). Vol. I. São Paulo: Edições Loyola, 2017.

HEGEL, Georg W.F. Linhas fundamentais da filosofia do direito ou Direito Natural e ciência do Estado em compêndio. Tradução Paulo Meneses [et al.]. São Leopoldo: Editora UNISINOS, 2010.

HEIDEGGER, Martin. Metaphysische Anfangsgründe der Logik im Ausgang Leibniz. Gesamtausgabe, vol. 26. Frankfurt am Main: Vittorio Klostermann, 1978.

HEIDEGGER, Martin. “Construir, habitar, pensar". In: HEIDEGGER, Martin. Ensaios e conferências. Petrópolis: Vozes, 2001. p. 125-141.

HÖSLE, Vittorio. Verità e storia. Studi sulla struttura dela storia dela filosofia sulla base di um'analisi paradigmática dell'evoluzione da Parmenide a Platone. Milano: Guerini e Associati, 1998.

HÖSLE, Vittorio. La crise du temps présent et la responsabilité de la philosophie. Nîmes: Théétète Éditions, 2004.

JARCZYC, Gwendoline e LABARRIÈRE, Pierre-Jean. De Kojève à Hegel. Cent cinquante ans de pensée hégélienne en France. Paris: Albin Michel, 1996.

KOSELLECK, Reinhart. Futuro passado. Contribuição à semântica dos tempos históricos. Rio de janeiro: Contraponto: Ed. PUC-Rio, 2006.

LEBRUN, Gérard. O avesso da dialética. Hegel à luz de Nietzsche. São Paulo: Companhia das Letras, 1988.

LÉONARD, André. "L' Absolut et l'histoire". In: VV.AA. Hegel et la théologie contemporaine. Paris/Neuchatel: Delachaux et Niestlé Éditeurs, 1977. p. 81-93.

LIMA VAZ, Henrique C. de (1952-1953). Contemplação e dialética nos diálogos platônicos. Tradução do latim para o português feita por Juvenal Savian Filho. São Paulo: edições Loyola/Fapemig, 2012. 
LIMA VAZ, Henrique C. (1959) "Marxismo e ontologia" . In: LIMA VAZ, Henrique C. de. Ontologia e história. São Paulo: Edições Loyola, 2001a. p. 121-161.

LIMA VAZ, Henrique C. (1960) “Cristianismo e consciência histórica I". In: LIMA VAZ, Henrique C. de. Ontologia e história. São Paulo: Edições Loyola, 2001a. p. 165-187.

LIMA VAZ, Henrique C. de (1961). "Cristianismo e consciência histórica II". In: LIMA VAZ, Henrique C. de. Ontologia e história. São Paulo: Edições Loyola, 2001a. p. 189-217.

LIMA VAZ, Henrique C. de (1966). “O absoluto e a história" (1966). In: LIMA VAZ, Henrique C. de. Ontologia e história. São Paulo: Edições Loyola, 2001 a. p. 247-278.

LIMA VAZ, Henrique C. de. (1970) Ateísmo e mito. A propósito do ateísmo do jovem Marx. Revista Portuguesa de Filosofia, 26 (1970): 20-50.

LIMA VAZ, Henrique C. "Meu depoimento" (1976). In: LADUSANS, Stanislavs. Rumos da filosofia atual no Brasil em autorretratos. São Paulo: Edições Loyola, 1976. p. 299-311.

LIMA VAZ, Henrique C. de (1981). "Senhor e escravo: uma parábola da filosofia ocidental”. Síntese. Nova Fase. Vol. VIII, n. 21 (1981): 7-30.

LIMA VAZ, Henrique C. de. (1991a). Antropologia Filosófica I. São Paulo: Edições Loyola, 2001.

LIMA VAZ, Henrique C. de. (1991b). "Morte e vida da filosofia". Síntese. Nova Fase. Vol.. XVIII, n. 55 (1991): 677-691.

LIMA VAZ, Henrique C. de. (1995). “Ética e razão moderna”. Síntese Nova Fase. Vol. XXII, n. 68 (1995): 53-85

LIMA VAZ, Henrique C. de. (1997a). “Filosofia e forma da ação. Uma entrevista de Henrique Cláudio de Lima Vaz". Cadernos de filosofia alemãa. N. 2 (1997): 77-102

LIMA VAZ, Henrique C. de. (1997b) "Atualidade da sabedoria antiga". Síntese Nova Fase. Vol. XXIV, n. 78 (1997): 411-420.

LIMA VAZ, Henrique C. de. (1997c). Escritos de filosofia III. Filosofia e cultura. São Paulo: Edições Loyola, 1997.

LIMA VAZ, Henrique C. de. (2001) "Humanismo hoje: tradição e missão". Síntese. Revista de Filosofia. Vol. XXVIII, n. 91 (2001): 157-158.

LIMA VAZ, Henrique C. de (2002). Escritos de filosofia VII. Raízes da modernidade. São Paulo: Edições Loyola, 2002.

NIETZSCHE, Friedrich. Sobre verdade e mentira no sentido extra-moral. São Paulo: Hedra, 2007.

NIETZSCHE, Friedrich. Fragmentos póstumos (1885-1887). Vol. VI. Tradução Marco Antônio Casanova. Rio de janeiro: Forense Universitária, 2013.

NIETZSCHE, Friedrich. Fragmentos póstumos (1887-1889). Tradução Marco Antônio Casanova. Vol. VII. Rio de janeiro: Forense Universitária, 2012.

OLIVEIRA, Manfredo Araújo de. Sobre a fundamentação. Porto Alegre: EDIPUCRS, 1993. 
PRADELLE, Dominique. Généalogie de la raison. Essai sur la historicité du sujet transcendental de Kant a Heidegger. Paris: PUF, 2013.

THOMAS-FOGIEL, Isabelle. Référence et autoréférence. Étude sur le thème de la mort de la philosophie dans la pensée contemporaine. Paris: Vrin, 2005.

VIOULAC, Jean. La logique totalitaire. Essai sur la crise de l'Occident. Paris: PUF, 2013.

WALLACE-WELLS, David. A terra inabitável. Uma história do futuro. São Paulo: Companhia das Letras, 2019.

WILLIAMS, Robert R. Hegel on the proofs and the Personhood of God. Studies in Hegel's Logic and Philosophy of Religion. Oxford: Oxford University Press, 2017.

ZIZEK, Slavoj. Menos que nada. Hegel e a sombra do materialismo dialético. São Paulo: Boitempo, 2013.

Endereço do Autor:

Av. Dr. Cristiano Guimarães 2127

Bairro Planalto

31720-300 Belo Horizonte - MG

carlosdrawin@yahoo.com.br 